\title{
Development of pickle from Thai pangus (Pangasianodon hypophthalamus) muscle and changes in it's nutritional composition during storage
}

\author{
$\bowtie$ Fatema Hoque Shikha ${ }^{1}$, Md. Ismail Hossain ${ }^{1}$, Khaleda Akter ${ }^{1}$ and Md. Arifur Rahman ${ }^{2}$ \\ ${ }^{1}$ Department of Fisheries Technology, Bangladesh Agricultural University, Mymensingh-2202, Bangladesh \\ ${ }^{2}$ Department of Graduate School, Nha Trang University, Nha Trang, Vietnam
}

\begin{tabular}{l}
\hline ARTICLE INFO \\
\hline Article history: \\
Received: 25 November 2018 \\
Accepted: 05 December 2018 \\
Published: 31 December 2018 \\
\hline Keywords: \\
Fish pickle; Pangasianodon \\
hypophthalmus; proximate \\
composition, room temperature \\
(30-35 ${ }^{\circ}$ C) \\
\hline Correspondence: \\
Fatema Hoque Shikha \\
\: shikhafh@bau.edu.bd
\end{tabular}

\begin{abstract}
Fish pickle was developed from Thai pangus (Pangasianodon hypophthalamus) fish muscle by using different types of food additives. Mustard oil and soybean oil were used for preparing fish pickle. Dorsal muscle and whole fish muscle without bone were used as raw material for preparing fish pickle. Changes in nutritional composition, $\mathrm{pH}$, bacteriological and sensory attributes were determined at room temperature $\left(30-35^{\circ} \mathrm{C}\right)$ according to standard procedures. At room temperature $\left(30-35^{\circ} \mathrm{C}\right)$ fish pickle prepared from dorsal muscle and whole fish muscle using both mustard oil and soybean oil remained in acceptable condition until 12/13 days. Bad smell produced in the pickle after $15^{\text {th }}$ day of storage. Moisture, protein, lipid and $\mathrm{pH}$ value decreased but ash content increased with the progress of storage period. In case of soybean oil used pickle deterioration was faster than the pickles prepared using mustard oil. Bacterial load was higher in soybean oil pickle and the pickle prepared from whole fish muscle.
\end{abstract}

@bau.edu.bd

Copyright:

c. (i)

(92018 by authors and BAURES. This work is licensed under the Creative Commons Attribution International License (CC By 4.0).

\section{Introduction}

It is well known that fish flesh has some unique characteristics as having high protein content with balanced profile of amino acids, polyunsaturated and essential fatty acids with $\omega-3$ series of fatty acids and low level of harmful cholesterol and saturated fat (Edwards and Kaewpaitoon, 1981).

Fish can act not only as a source of protein to human being, but also provide foreign exchange earning to many people when the harvesting, handling and processing methods done in the right way and time (Mazrouh MM. 2015). In addition, preservation and processing can assure availability of fish in all year round (Smida MAB, 2014 and Oparaku et. al., 2013) The bio-chemical composition of fish is the vital aspect in fish processing, because which influences both the quality and technological characteristics of it (Farid FB et. al., 2014) Different processing methods of fish have different effect on their chemical, physical and nutritional compositions (Akinneye JO et. al., 2010) The effect could be either chemical or physical changes, which affects digestibility due to protein denaturation and reduction in the content of mobile compounds and polyunsaturated fatty acids. The quality and shelf life of fish differs using different methods and has different acceptability by consumers (Mojisola O., 2014). During fish processing several changes is occurred. Depending on the extent of heating and temperature protein denaturation may resulted. Heating also brings deconformation of natural features of the protein molecules or complexes, resulting in exposure of the reactive groups. Most proteins are compounds liable to quality and quantity changes during heat processing. The loss of solubility of temperature sensitive proteins can be utilized as an indicator of the time and temperature that had been applied in heat processing of varieties of fish and fish products (Akinneye JO et. al., 2010; Alipour HJ et. al. 2010; Sarker ZI et. al., 2012 and Sriket $\mathrm{P}$ et. al., 2007). Sriket P. et al., 2007 and El \& Kavas 91996) reported that protein digestibility is reduced as a result of complex chemical (cross-linking) reactions, such as protein interactions or protein-fat interactions when fish is boiled at high temperatures. Pourshamsian K. et al. (2012) noted that frying has an effect on proximate composition and fatty acids of fish and fish products. Nevertheless, no basic information regarding the effect of processing methods on nutritional and physicochemical composition of fish processed in Eritrea fish processing plants (Eri-fish processing plant and Eritrea Marine Product Company) has been reported (https://medcraveonline.com/MOJFPT/MOJFPT-0600191.pdf).

Pickling is a safe and easy method of putting up fish for short term storage when carefully prepared under most hygienic conditions with addition of required quantity of salt, preservatives and spices (Sharma and Sarma, 2012). Most of the sea fish like prawn, tuna, pomfret, mackerel, 
etc. are ideally suitable for making fish pickles (http://cift.res.in/fish-pickle). Preserving fish through pickling is a universal method and in South Africa what sets this apart is the addition of flavorful spices (http://eprints.cmfri.org.in/1842/1/Article_10.pdf). For effective capacity utilization and potential production of diversified products, processing of the underutilized fish species into value added products will bring immediate benefit to the existing fish processing industries in Bangladesh (Nowsad et al., 1994). Therefore it is very important to develop new processing techniques of underutilized protein resources to make them useful and palatable food for human consumption. In Bangladesh almost no publication is available on the development of fish pickle and it's shelf life. So, it is important to explore researches on developing fish pickles from available low cost fishes and also on their storage life under various conditions.

Pangus catfish, commonly called Thai pangus (Pangasianodon hypophthalamus) a low priced fish in fish markets. On the other hand the smell and pinkish color of pungas muscle are not much suitable to produce fillet of high grade. But this pungas muscle would serve as an adequate source of raw material for preparing fish pickle. As picking undergoes with the addition of different ingredients and cooking operation so it may provide a product of sub continental familiar taste and also fish protein to young and outgoing people in "ready to eat" form. A sustainable aquaculture of pangus catfish can be achieved by increasing its utilization in the development of diversified fishery products like fish pickle. At the same time the farmer can earn handsome money by supplying fish to the pickle producing companies Considering these facts, current study was designed to develop fish pickle from the dorsal muscle and whole Thai pangus fish muscle using mustard oil and soybean oil and observing the changes in nutritional composition, $\mathrm{pH}$, bacteriological and sensory attributes stored at room temperature $\left(30-35^{\circ} \mathrm{C}\right)$.

\section{Materials and Methods \\ Duration of the Study}

The present study was conducted in April-May, 2013 (From January to March, 2013 was trial period), in the laboratories of Fisheries Technology Department of Bangladesh Agricultural University, Mymensingh.

\section{Sources of Samples}

The samples (Thai pangus; Pangasianodon hypophthalamus) were collected from Kamal- Ranjit (KR) market of Bangladesh Agricultural University, Mymensingh in fresh condition. These were immediately transported to the Fish Processing laboratory of Fisheries Technology Department.

\section{Preparation of Fish Pickle}

\section{Ingredients for Fish Pickle}

Fish pickle was prepared from the collected fish according to the method described below. Standard recipe for the preparation of pickle and condiment are given in the following Table 1.
Table 1. Standard Recipe for Fish Pickle Preparation

\begin{tabular}{lclc}
\hline Ingredient name & Amount & Ingredient name & Amount \\
\hline Fish muscle & $500 \mathrm{~g}$ & Vinegar & $50 \mathrm{ml}$ \\
Chili powder & $20 \mathrm{~g}$ & Black pepper & $2 \mathrm{~g}$ \\
Turmeric powder & $2 \mathrm{~g}$ & Pach foron & $5 \mathrm{~g}$ \\
Cumin & $10 \mathrm{~g}$ & Sugar & $50 \mathrm{~g}$ \\
Onion & $20 \mathrm{~g}$ & Salt & $30 \mathrm{~g}$ \\
Garlic & $80 \mathrm{~g}$ & Tomato sauce & $30 \mathrm{~g}$ \\
Ginger & $10 \mathrm{~g}$ & Tamarind & $20 \mathrm{~g}$ \\
Cloves & $2 \mathrm{~g}$ & Sodium benzoate & $1 \mathrm{~g}$ \\
Mustard oil & $150 \mathrm{ml}$ & & \\
\hline
\end{tabular}

\section{Fish Pickle Preparation Procedure}

The fishes were thoroughly washed with tap water to remove contaminants on the skin. Then the fishes were cut into small pieces (approx. $1 \mathrm{~cm}^{3}$ ) using sharp knife and washed with tap water in the laboratory to remove bloods and other contaminants. The pieces were marinated, fried in mustard oil, added other ingredients and finally heated till vinegar absorbed. During packing care was taken to see that there was layer of oil over the contents in the bottles. The detail procedure is as follows-

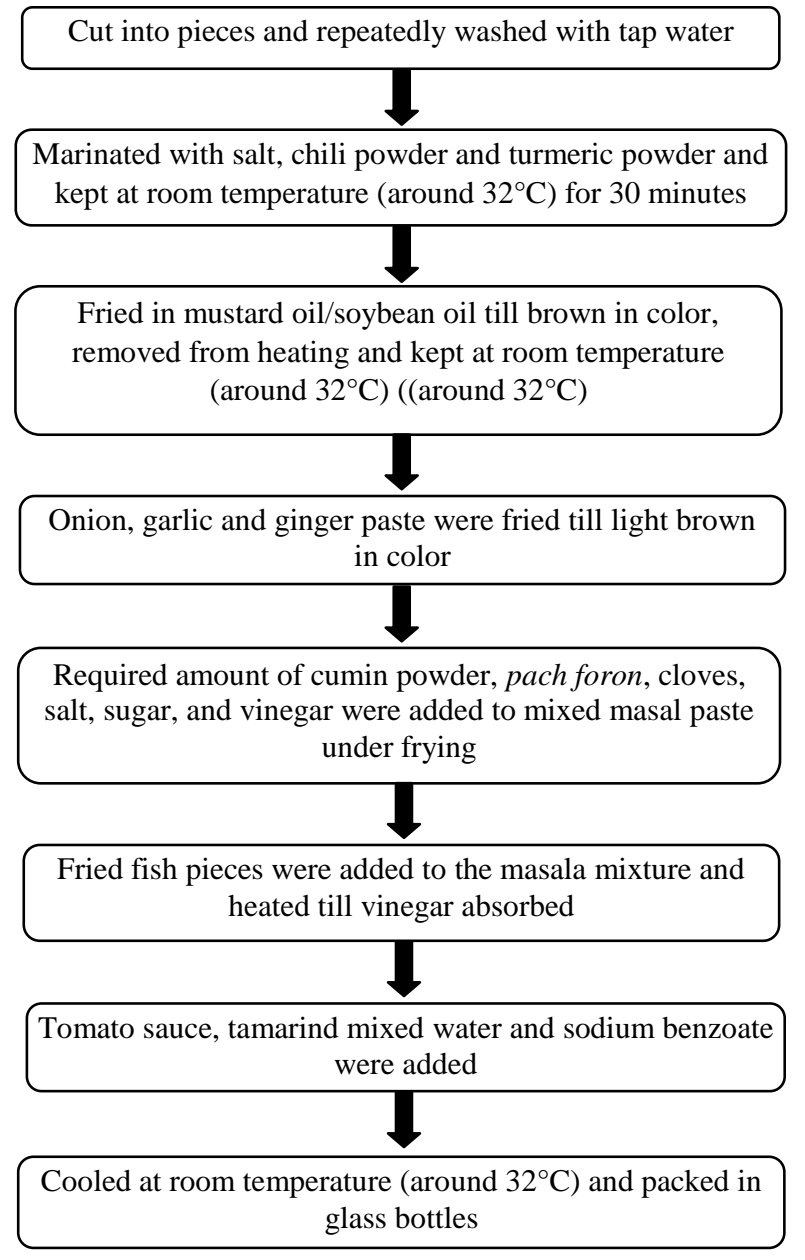

Flow Diagram of Fish Pickle Preparation 


\section{Sample Storage:}

Prepared pickle samples were stored at room temperature $\left(30-35^{\circ} \mathrm{C}\right)$ in 12 glass bottles for around 20 days. Each of the bottles contained 300g pickle. Among these 12 bottles- pickle prepared from dorsal muscle with mustard oil were stored in 3 bottles, pickle prepared from dorsal muscle with soybean oil were stored in another 3 bottles. Pickle prepared from whole fish muscle also stored in $3+3$ separate bottles for mustard oil and soybean oil.

\section{Quality Analysis}

Weekly analysis of the samples were done for 15 days at room temperature $\left(30-35^{\circ} \mathrm{C}\right)$. Triplicate samples were taken to carry out the experiment. Proximate composition (moisture, protein, lipid and ash) of fish pickle were tested according to the standard methods described by Association of Official Analytical Chemists (AOAC, 2005).

\section{Determination of $\mathrm{pH}$ value}

$\mathrm{pH}$ was measured at room temperature following the method described by AOAC (2005). At first accurately $5 \mathrm{~g}$ sample was taken and homogenously mixed in $50 \mathrm{ml}$ distilled water. $\mathrm{pH}$ was measured using an electronic $\mathrm{pH}$ meter (HANNA pH 211 Microprocessor pH Meter) with a glass electrode using expandable scale.

\section{Determination of APC}

The colonies units (CFU) were counted under a Quebec dark field colony counter (Leica, Buffalo. NY. USA) equipped with a guide plate ruled in square centimeters. Plates containing 30-300 colonies were used to calculate bacterial load using following formula:

$$
\operatorname{APC}\left(\frac{\mathrm{CFU}}{\mathrm{g}}\right)=
$$

No of colonies on petridish $\times$ Dilution factor $\times$ Vol.of stock solution $\times 10$

Wt. of pickle or condiment sample

\section{Sensory evaluation}

A panel of nine persons of teachers and students of the Department of Fisheries Technology provided the sensory assessments of the products (Nowsad et al., 2000). Sensory evaluation of the fish pickle was conducted according to the grade $9=$ Like extremely, 8 = Like very much, $7=$ Like moderately, $6=$ Like slightly, 5 = Neither like nor dislike, $4=$ Dislike slightly, 3 = Dislike moderately, 2 = Dislike very much, $1=$ Dislike extremely. Chewiness / Rubberiness were defined as the amount of effort the panelist had to exert in chewing to prepare the sample for swallowing. Color and flavor were evaluated organoleptically.

\section{Statistical Analysis}

One-way analysis of variance and the general linear model using Windows for SPSS 9.0 were used to analyze the data. The Duncan "s New Multiple Range Test (DMRT) was used to find the significant differences between storage periods.

\section{Results}

Biochemical Composition of Fresh Fish

The fish collected from the Kamal-Ranjit market of Bangladesh Agricultural University were fresh and many of them were in live condition. The initial chemical composition of fresh fish samples obtained as protein content $13.92 \%$, lipid content $4.93 \%$, moisture content $78.61 \%$ and ash content $2.25 \%$ (Table 2 ).

Table 2. Proximate Composition (average value) of the Fresh Thai pangus (Pangasianodon hypophthalamus) Muscle

\begin{tabular}{lc}
\hline Parameters & Results (\%) \\
\hline Moisture & $78.61 \pm 0.76$ \\
Protein & $13.92 \pm 0.62$ \\
Lipid & $4.93 \pm 0.12$ \\
Ash & $2.25 \pm 0.06$ \\
\hline
\end{tabular}

Changes in the Protein Content of Fish Pickle

The initial protein content was $13.92 \%$ in fish body. After preparing fish pickle with mustard oil and soybean oil the protein content reached to $19.47 \%$ and $16.15 \%$ (pickle prepared with dorsal muscle) and $19.07 \%$ and $16.62 \%$ (pickled prepared with whole fish muscle), respectively. As the time passed, protein content mostly decreased. In case of pickle prepared with dorsal muscle (using mustard oil), after 7days of storage protein content reached to $17.67 \%$, then after 15 days of storage more deterioration occurred and the value reached to $15.99 \%$. While soybean oil was used to prepare pickle these values were $15.85 \%$ (after 7 days) and $15.45 \%$ (after 15 days), respectively (Table 3). On the other hand fish pickle prepared with whole fish muscle using both mustard oil and soybean oil slight differences in the protein content were observed. Fish pickle prepared with whole fish muscle (using mustard oil), protein content reached to $17.81 \%$ after 7 days of storage and after 15 days of storage $16.38 \%$. While pickle was prepared using soybean oil (with whole fish) the obtained values were $16.30 \%$ (after 7 days) and $15.97 \%$ (after 15 days), respectively (Table 3 ).

\section{Changes in the Lipid Content of Fish Pickle}

The changes in the lipid content (\%) of fish pickle prepared with dorsal muscle during storage period of 15 days at room temperature $\left(30-35^{\circ} \mathrm{C}\right)$ are shown in Table 4. The initial lipid content of fresh fish was $4.93 \%$. After preparing pickle using mustard oil and different spices it reached to $17.57 \%$. As the time passed the lipid content gradually decreased and reached to $16.78 \%$ after 7 days of storage and after 15 days of storage to $15.38 \%$. In the pickle prepared using soybean oil the lipid content reached to $18.28 \%$ which is greater than the sample prepared using mustard oil. As the time passed lipid content gradually decreased to $17.38 \%$ after 7 days of storage then after 15 days of storage it declined to $16.68 \%$. On the other hand, the lipid content of fish pickle prepared with whole fish muscle using mustard oil during the storage period of 15 days reached to 
$22.59 \%$. As the time passed lipid content gradually declined to $20.42 \%$ after 7 days of storage and after 15 days of storage it decreased to $17.18 \%$. In fish pickle prepared using soybean oil from whole fish the lipid content reached to $25.58 \%$ initially which is greater than the sample prepared using mustard oil. As the time passed lipid content gradually decreased to $22.78 \%$ after 7 days then after 15 days of storage it declined to $19.58 \%$ (Table 4).

\section{Changes in the Moisture Content of Fish Pickle}

Changes in the moisture content $(\%)$ of fish pickle prepared with dorsal muscle during storage period of 15 days at room temperature $\left(30-35^{\circ} \mathrm{C}\right)$ are shown in Table 5. The initial moisture content of fresh fish was $78.87 \%$. Moisture content of fish pickle was $57.25 \%$ on ' 0 'day for mustard oil pickle which decreased gradually after 7 days of storage it declined to $42.06 \%$ and on 15 days of storage the value was obtained $36.92 \%$. In case of fish pickle prepared using soybean oil the moisture content reduced from $51.41 \%$ to $45.85 \%$ after 7 days of storage and on 15 days of storage it declined to $39.28 \%$. In case of soybean oil, moisture reduction was lower than mustard oil. Changes in the moisture content of fish pickle prepared with whole fish muscle during storage period of 15 days at room temperature $\left(30-35^{\circ} \mathrm{C}\right)$ are shown in Table 4. In this case, the moisture content was $56.69 \%$ on ' 0 'day for mustard oil pickle which decreased gradually after 7 days of storage, it declined to $55.25 \%$ and on 15 days of storage the value was obtained $53.56 \%$. On the other hand, fish pickle made with soybean oil, the moisture content reduced from $51.81 \%$ to $49.71 \%$ after 7 days of storage and on 15 days of storage it declined to $47.31 \%$. In case mustard oil pickle, the fungal growth was lower than the soybean oil pickle.

\section{Changes in the Ash Content of Fish Pickle}

The changes in the ash content (\%) of fish pickle prepared with dorsal muscle during storage period of 15 days at room temperature $\left(30-35^{\circ} \mathrm{C}\right)$ are shown in Table 6. The ash content of pickle prepared using mustard oil was $4.31 \%$ on ' 0 ' day. The ash content started to increase gradually as the fish muscle liquefied. After 7 days of storage it reached to $4.92 \%$ and it reached to $5.22 \%$ on 15 days of storage. In case of soybean oil used pickle the value was $5.21 \%$ on ' 0 ' day which reached to $5.32 \%$ after 7 days of storage and to $5.52 \%$ on 15 days of storage. The changes in the ash content of fish pickle prepared with whole fish muscle during storage period of 15 days are also shown in Table 6. Here, the value for pickle prepared using mustard oil was $4.25 \%$ on ' 0 ' day. After 7 days of storage it reached to $4.61 \%$ and to $5.11 \%$ on 15 days of storage. The ash content of fish pickle prepared with whole fish muscle by using soybean oil was $4.36 \%$ on ' 0 ' day which reached to $4.81 \%$ after 7 days of storage and to $5.66 \%$ on 15 days of storage.

Table 3. Changes in the Protein Content (\%) of Fish Pickle (Dorsal and Whole Fish Muscle) during Storage Period of 15 days at $\operatorname{Room}$ Temperature $\left(30-35^{\circ} \mathrm{C}\right)$

\begin{tabular}{clccc}
\hline \multirow{2}{*}{ Days } & \multicolumn{4}{c}{ Protein Content (\%) } \\
\cline { 2 - 5 } & \multicolumn{2}{c}{ Dorsal Muscle } & \multicolumn{2}{c}{ Whole Fish Muscle } \\
\cline { 2 - 5 } & Mustard Oil & Soybean Oil & Mustard Oil & Soybean Oil \\
\hline 0 & $19.47 \pm 0.43$ & $16.15 \pm 0.41$ & $19.07 \pm 0.35$ & $16.62 \pm 0.28$ \\
7 & $17.67 \pm 0.35$ & $15.85 \pm 0.29$ & $17.81 \pm 0.29$ & $16.30 \pm 0.23$ \\
15 & $15.99 \pm 0.30$ & $15.45 \pm 0.25$ & $16.38 \pm 0.19$ & $15.97 \pm 0.15$ \\
\hline
\end{tabular}

*mean value \pm standard deviation of 3 individual measurement

Table 4. Changes in the Lipid Content (\%) of Fish Pickle (Dorsal and Whole Fish Muscle) during Storage Period of 15 days at Room Temperature $\left(30-35^{\circ} \mathrm{C}\right)$

\begin{tabular}{clccc}
\hline \multirow{2}{*}{ Days } & \multicolumn{3}{c}{ Lipid Content (\%) } \\
\cline { 2 - 5 } & \multicolumn{2}{c}{ Dorsal Muscle } & \multicolumn{2}{c}{ Whole Fish Muscle } \\
\cline { 2 - 5 } & Mustard Oil & Soybean Oil & Mustard Oil & Soybean Oil \\
\hline 0 & $17.57 \pm 0.14$ & $18.28 \pm 0.11$ & $22.59 \pm 0.41$ & $25.58 \pm 0.29$ \\
7 & $16.78 \pm 0.28$ & $17.38 \pm 0.19$ & $20.42 \pm 0.32$ & $22.78 \pm 0.17$ \\
15 & $15.38 \pm 0.12$ & $16.68 \pm 0.10$ & $17.18 \pm 0.25$ & $19.58 \pm 0.91$ \\
\hline
\end{tabular}

*mean value \pm standard deviation of 3 individual measurement

Table 5. Changes in the Moisture Content (\%) of Fish Pickle (Dorsal and Whole Fish Muscle) during Storage Period of 15 days at Room Temperature $\left(30-35^{\circ} \mathrm{C}\right)$

\begin{tabular}{cllll}
\hline \multirow{2}{*}{ Days } & \multicolumn{3}{c}{ Moisture Content (\%) } \\
\cline { 2 - 5 } & \multicolumn{2}{c}{ Dorsal muscle } & \multicolumn{2}{c}{ Whole Fish Muscle } \\
\cline { 2 - 5 } & Mustard Oil & Soybean Oil & Mustard Oil & Soybean Oil \\
\hline 0 & $57.25 \pm 0.75$ & $51.41 \pm 0.65$ & $56.69 \pm 0.72$ & $51.81 \pm 0.69$ \\
7 & $42.06 \pm 0.76$ & $45.85 \pm 0.61$ & $55.25 \pm 0.82$ & $49.71 \pm 0.78$ \\
15 & $36.92 \pm 0.68$ & $39.28 \pm 0.52$ & $53.56 \pm 0.56$ & $47.31 \pm 0.71$ \\
\hline
\end{tabular}

*mean value \pm standard deviation of 3 individual measurement 
Table 6. Changes in the Ash Content (\%) of Fish Pickle (Dorsal and Whole Fish Muscle) during Storage Period of 15 days at Room Temperature $\left(30-35^{\circ} \mathrm{C}\right)$

\begin{tabular}{clccc}
\hline \multirow{3}{*}{ Days } & \multicolumn{4}{c}{ Ash Content (\%) } \\
\cline { 2 - 5 } & \multicolumn{3}{c}{ Dorsal Muscle } & \multicolumn{2}{c}{ Whole Fish Muscle } \\
\cline { 2 - 5 } & Mustard oil & Soybean oil & Mustard oil & Soybean oil \\
\hline 0 & $4.31 \pm 0.05$ & $5.21 \pm 0.10$ & $4.25 \pm 0.08$ & $4.36 \pm 0.05$ \\
7 & $4.92 \pm 0.08$ & $5.32 \pm 0.11$ & $4.61 \pm 0.11$ & $4.81 \pm 0.03$ \\
15 & $5.22 \pm 0.12$ & $5.52 \pm 0.18$ & $5.11 \pm 0.15$ & $5.66 \pm 0.09$ \\
\hline
\end{tabular}

*mean value \pm standard deviation of 3 individual measurement

\section{Changes in the pH Value of Fish Pickle}

The changes in the $\mathrm{pH}$ value of fish pickle prepared from dorsal muscle during storage period of 15 days at room temperature $\left(30-35^{\circ} \mathrm{C}\right)$ are shown in Table 7 . The $\mathrm{pH}$ value of fish pickle prepared with dorsal muscle using mustard oil at room temperature was 4.54 on ' 0 'day, as the time passed, it increased. After 7 days of storage it reached to 4.45 and after 15 days of storage it reached to 4.36 . The $\mathrm{pH}$ value of pickle prepared using soybean oil was 4.91 which reached to 4.82 after 7 days and to 4.75 after 15 days of storage. On the other hand, the $\mathrm{pH}$ value of fish pickle prepared with whole fish muscle using mustard oil at room temperature was 4.60 on ' 0 ' which decreased to 4.34 after 7 days of storage. But after 15 days of storage increased and reached to 4.04. The $\mathrm{pH}$ value of fish pickle prepared with whole fish muscle using soybean oil at room temperature was 4.43. After 7 days of storage the value declined to 4.38 and after 15 days it reached to 4.31 .

\section{Changes in the Bacterial Load of Fish Pickle}

Changes in the bacterial load in fish pickle prepared with dorsal muscle during storage period of 15 days at room temperature $\left(30-35^{\circ} \mathrm{C}\right)$ are shown in Table 8 . In case of sample prepared using mustard oil the bacterial load increased throughout the storage period. Here, the initial bacterial load of fish pickle was $2.5 \times 10^{3} \mathrm{CFU} / \mathrm{g}$. With the progress of storage time on 7 days of storage it increased to $3.3 \times 10^{5} \mathrm{CFU} / \mathrm{g}$ and after 15 days of storage the value found $5.2 \times 10^{7} \mathrm{CFU} / \mathrm{g}$. On the other hand sample prepared using soybean oil the initial bacterial load of fish pickle was $3.0 \times 10^{3} \mathrm{CFU} / \mathrm{g}$, which increased to $3.7 \times 10^{6} \mathrm{CFU} / \mathrm{g}$ after 7 days and to $7.2 \times 10^{8} \mathrm{CFU} / \mathrm{g}$ after 15 days of storage. These results showed that bacterial load is higher in pickle prepared using soybean oil than mustard oil. Changes in the bacterial load in fish pickle prepared with whole fish muscle during storage period of 15 days at room temperature $\left(30-35^{\circ} \mathrm{C}\right)$ are also shown in Table 8. In this case the pickle prepared using mustard oil bacterial load increased throughout the storage period. The initial bacterial load was $3.7 \times 10^{5}$ $\mathrm{CFU} / \mathrm{g}$ which increased with the progress of storage time. On $7^{\text {th }}$ days of storage bacterial load increased to $5.2 \times 10^{7} \mathrm{CFU} / \mathrm{g}$ and after 15 days of storage this value reached to $8.9 \times 10^{8} \mathrm{CFU} / \mathrm{g}$. On the other hand the pickle prepared using soybean oil the initial bacterial load was $4.2 \times 10^{5} \mathrm{CFU} / \mathrm{g}$. After 7 days of storage the value increased to $6.5 \times 10^{7} \mathrm{CFU} / \mathrm{g}$ and then after 15 days of storage the value reached to $9.2 \times 10^{8} \mathrm{CFU} / \mathrm{g}$. Pickle prepared with whole fish muscle also showed the similar trend as was for pickle prepared with dorsal muscle.

\section{Sensory Evaluation}

The results of changes in sensory quality attributes of fish pickles during storage at room temperature (30$35^{\circ} \mathrm{C}$ ) are shown in Table 9. The sensory attributes changed with the progress of storage period. The prepared pickles mostly deteriorated after 15 days of storage. Fish pickle prepared by using mustard oil was more accepted than soybean oil by panelists. They almost equally accepted the fish pickles prepared from both dorsal muscle and whole fish muscle.

Table 7. Changes in pH value of Fish Pickle (Dorsal and Whole Fish Muscle) during Storage Period of 15 days at Room Temperature $\left(30-35^{\circ} \mathrm{C}\right)$

\begin{tabular}{ccccc}
\hline \multirow{2}{*}{ Days } & \multicolumn{4}{c}{ pH Value } \\
\cline { 2 - 5 } & \multicolumn{2}{c}{ Dorsal Muscle } & \multicolumn{2}{c}{ Whole Fish Muscle } \\
\cline { 2 - 5 } & Mustard Oil & Soybean Oil & Mustard Oil & Soybean Oil \\
\hline 0 & $4.54 \pm 0.02$ & $4.91 \pm 0.32$ & $4.60 \pm 0.10$ & $4.43 \pm 0.11$ \\
7 & $4.45 \pm 0.27$ & $4.82 \pm 0.04$ & $4.34 \pm 0.05$ & $4.38 \pm 0.09$ \\
15 & $4.36 \pm 0.06$ & $4.75 \pm 0.08$ & $4.04 \pm 0.07$ & $4.31 \pm 0.16$ \\
\hline
\end{tabular}

*mean value \pm standard deviation of 3 individual measurement 
Table 8. Changes in Bacterial load (CFU/g) of Fish Pickle (Dorsal and Whole Fish Muscle) during Storage Period of 15 days at Room Temperature $\left(30-35^{\circ} \mathrm{C}\right)$

\begin{tabular}{ccccc}
\hline Days & \multicolumn{4}{c}{ Bacterial load (CFU/g) } \\
\cline { 2 - 5 } & \multicolumn{2}{c}{ Dorsal Muscle } & \multicolumn{2}{c}{ Whole Fish Muscle } \\
\cline { 2 - 5 } & Mustard & Soybean & Mustard & Oil \\
& Oil & Oil & $3.7 \times 10^{5}$ & Oil \\
\hline 0 & $2.5 \times 10^{3}$ & $3.0 \times 10^{3}$ & $5.2 \times 10^{7}$ & $4.2 \times 10^{5}$ \\
7 & $3.3 \times 10^{5}$ & $3.7 \times 10^{6}$ & $6.5 \times 10^{7}$ \\
15 & $5.2 \times 10^{7}$ & $7.2 \times 10^{8}$ & $8.9 \times 10^{8}$ & $9.2 \times 10^{8}$ \\
\hline
\end{tabular}

Table 9. Changes in Sensory Quality Attributes of Fish Pickle (Dorsal and Whole Fish Muscle) during Storage Period of 15 days at Room Temperature $\left(30-35^{\circ} \mathrm{C}\right)$

\begin{tabular}{cccccc}
\hline Pickle Type & $\begin{array}{c}\text { Storage period } \\
\text { (Day) }\end{array}$ & Color & Flavor & Texture & $\begin{array}{c}\text { General } \\
\text { acceptability }\end{array}$ \\
\hline Dorsal Muscle+ & 0 & 9 & 9 & 9 & 9 \\
Mustard Oil & 7 & 9 & 8 & 9 & 0 \\
& 15 & Rejected & Rejected & Rejected & Rejected \\
Dorsal Muscle+ & 0 & 8 & 8 & 9 & 8 \\
Soybean Oil & 7 & 8 & 7 & 7 & 7 \\
Whole Fish & 15 & Rejected & Rejected & Rejected & Rejected \\
Muscle+ Mustard & 0 & 9 & 9 & 9 & 9 \\
Oil & 7 & 9 & 8 & 8 & 9 \\
Whole Fish & 0 & Rejected & Rejected & Rejected & Rejected \\
Muscle+ Soybean & 7 & 8 & 7 & 8 & 7 \\
Oil & 15 & 8 & 7 & 7 & 7 \\
\hline
\end{tabular}

N.B $9=$ Like extremely, $8=$ Like very much, $7=$ Like moderately, $6=$ Like slightly, $5=$ Neither like nor dislike, $4=$ Dislike slightly, 3 = Dislike moderately, 2 = Dislike very much, 1 = Dislike extremely.

\section{Discussion}

The proximate composition and its variation in edible and inedible parts of freshwater fish species of Bangladesh was reported by Chakraborty et al. (2003). The highest protein content found $20.14 \%$ in Labeo boga, the lipid content was $17.80 \%$ in Hilsa ilisha and the ash content was 4.38 Setipinna phasa. On the other hand the lowest values of these parameters were 13.50, 1.30 and $1.00 \%$ respectively in Chanda nama, Glossogobius giuris and Chanda reticulata. This finding establishes the fact that freshwater fishes of Bangladesh are in the category of high protein food. The proximate composition of fish reported by Stansby (1962) was in the ranges of moisture 28 to $90 \%$, protein 6 to $28.9 \%$, crude fat 0.2 to $64 \%$ and ash 0.4 to $1.5 \%$. Ejaz et al. (2009) found protein content $23.01 \%$, lipid content $4.89 \%$, moisture content $70.15 \%$, ash content $2.01 \%$ and $\mathrm{pH} 6.8$ in the mince of pangus fish. All these findings more or less support the findings of the present study.

Data on chemical composition of fish products like fish pickle are scare. Parvin et al (2010) prepared fish pickles (with olive and tamarind) from mola fish (Amblypharyngodon mola) and studied their nutritional and food quality. The quality of the pickle prepared with olive was excellent and the pickle prepared with tamarind was found good. Moisture content of the two pickle products were $43.85 \%$ (with tamarind) and $50.89 \%$ (with olive). The protein and lipid contents of tamarind added pickle were 19.13 and $35.64 \%$ respectively; pickle with olive contained less protein (13.16\%) compared to tamarind added mola pickle. Lipid contents were almost same in both cases. Ash content of two pickles was also found similar (1.00\%). Arannilewa et al. (2005) reported that protein content in fish and fishery products decrease during storage due to the denaturation of fish protein and leaching out of water soluble protein. McGill et al. (1974) reported that lipid content in fishery products started to decrease when oxidation occurs. The decline in moisture content is due to deep frying and dehydration during storage of the test samples (Ninan et al., 2008). Ash content increased due to moisture loss in the processed fish pickle during frying and cooking (Kocatepe et al., 2011) and another reason might be addition of different ingredients during pickle preparation Tanuja and Hameed (1998) recorded the $\mathrm{pH}$ of squilla pickle 4.46 which dropped gradually during storage. S S Patil et al. (2014) reported protein content $14.38 \%$, lipid content $17.16 \%$, moisture content $60.25 \%$, ash content $5.45 \%$ and $\mathrm{pH} 4.26$ in pickle prepared with pangus muscle on the $1^{\text {st }}$ day of preparation. These findings for fish pickle are nearer to the obtained results for fish pickles in most parameters of the present study. With the extension of storage period the sensory attributes changed and showed lower score for the prepared product in the present experiment coincides with findings of Kumar and Basu (2001). They reported, for shrimp pickle the overall acceptability rating showed a downward trend due to increase in peroxide and TVN value with the laps of storage period. 


\section{Conclusion}

The study could be concludes that-pangus fish muscle could be used for the preparation of fish pickle. In both cases pickles either prepared from dorsal muscle or whole fish muscle with mustard oil and stored at room temperature $\left(30-35^{\circ} \mathrm{C}\right)$ the moisture reduction was higher. In case of pickle prepared with soybean oil though the moisture content was lower but the smell was not accepted by the panelists. These findings indicated that-mustard oil is better than soybean oil for preparing fish pickle because its flavor is well known for any kind of pickle at this region. On the other hand the shelf life of prepared pickle from pangus fish mince is shorter, not more than 15 days at room temperature $\left(30-35^{\circ} \mathrm{C}\right)$.

\section{Acknowledgements}

This research was funded by Bangladesh Agricultural University Research System.

\section{References}

Akinneye JO, Amoo IA, Bakare OO. 2010. Effect of drying methods on the chemical composition of three species of fish (Bonga spp., Sardinella spp. and Heterotis niloticus). African Journal of Biotechnology, 9(28):4369-4373.

Alipour HJ, Shabanpoor B, Ali Shabani, et al. 2010. Effects of cooking methods on physico-chemical and nutritional properties of Persian sturgeon Acipenser persicus fillet. Internaional Aquatic Resource, 2:15-23.

AOAC, 2005. Official Methods of Analysis. Association of Official Analytical Chemists International, 18th edition, Washington (D. C.)

Arannilewa, S.T., Salawu, S.O., Sorungbe, A.A. and Ola-Salawu, B.B. 2005. Effect of frozen period on the chemical, microbiological and sensory quality of frozen tilapia fish (Sarotherodun galiaenus). African Journal of Biotechnology, 4(8): 852-855.

Chakraborty, S.C. 2003. A study on proximate composition of common fresh water fishes of Bangladesh. Bangladesh Journal of Fisheries. 26 (1-2): 23-36.

Edwards and Kaewpaitoon. 1981. "Fish Farming with Livestock Manure". Paper presented at a seminar on Maximum Livestock Production from Minimum Land, jointly organized by the Department of Animal Science, BAU, NYRDP-DANIDA, Bangladesh Agricultural University, Mymensingh 2-5 February, 1981.

Ejaz, M. A., Shikha, F. H. and Hossain, M. I. 2009. Preparation of fish burgar from pangus catfish (Pangasius sutchi) and evaluation of quality and shelf life during different storage conditions. Progress. Agric. 20(1 \& 2): $153-$ 162.

EL SN, Kavas A. 1996. Determination of protein quality of rainbow trout (Salmo irideus) by in vitro protein digestibility-corrected amino acid score (PDCAAS). Food Chemistry, 55(3):221-223. https://doi.org/ 10.1016/0308-8146(95)00111-5

Farid FB, Latifa GA, Nahid MN, et al. 2014. Effect of Sun-drying on proximate composition and $\mathrm{pH}$ of Shoal fish (C. striatus; Bloch, 1801) treated with Salt and Saltturmeric storage at Room Temperature $\left(27^{\circ} \mathrm{C}-30^{\circ} \mathrm{C}\right)$. IOSR Journal of Agriculture and Veterinary Science (IOSR-JAVS). 7(9): 1-8. https://doi.org/10.9790/238007930108

Kocatepe, D., Turan, H., Taskaya, G., Kaya, Y., Erden, R. and Erdogdu, F. 2011. Effects of cooking methods on the proximate composition of Black Sea anchovy
(Engraulis encrasicolus). Academic Food Journal (GIDA), 36(2): 71-75.

Kumar, S. and Basu, S. 2001. Preparation of Prawn pickle and it's storage characteristics. Journal of the Indian Fisheries Association 28: 105-111.

MacGill, A.S., Hard, R. and Burt, J.R. 1974. Hept-cis-4-enal and its contribution to the off flavour in cold stored cod. Journal of the Science of Food and Agriculture, 25: 1477-1489. https://doi.org/10.1002/jsfa.2740251208

Mazrouh MM. 2015. Effects of freezing storage on the biochemical composition in muscles of Saurida undosquamis (Richardson, 1848) comparing withimported frozen. International Journal of Fisheries and aquactic Science, 3(2):295-299.

Mojisola O. 2014. The Effect of Different Processing Methods on the Nutritional Quality and Microbiological Status of Cat Fish (Clarias lezera). Journal of Food Processing \& Technology, 5(6). https://doi.org/10.4172/ 21577110.1000333

Ninan, G., Bindu, J. and Joseph, J. 2008. Frozen storage studies of minced based products developed from tilapia (Oreochromis mossambicus, Peter 1852). Fishery Technology, 45(1): 35-42.

Nowsad, A. A., Kanoh, S., Chanda, S. C. and Niwa, E. 2000. The effects of heating and washing on the gelling properties of tropical major carp muscle. Journal of Aquatic Food Product Technology 8(2):5-23. https://doi.org/ 10.1300/J030v08n02 02

Nowsad, A.K.M.A. 1994. Raw material for the manufacture of surimi - II. The Bangladesh Observer, March 8 and 9, 1994, Dhaka, Bangladesh.

Oparaku, Nkiruka Francisca, Nwaka FC. 2013. Effect of processing on the nutritional qualities of three fish species (Synodontis clarias, Trachurus trecae and Clarias gariepinus). International Journal Of Biology and Biological Sciences, 2:143-149.

Patil, S. S, Pagarkar1, A.U, Chaudhary, K. J, Desai A. S and S. M. Shaikh. 2014. Organoleptic and Biochemical Quality Changes in Fish Pickle Prepared from Freshwater Catfsh Pangasius (Pangasianodon hypothalamus). The Indian veterinary journal 91(7):12-14.

Pervin, K, Nayeem, M.A., Newaz, A.W., Kamal, M., Yeasmine, S. and Nurullah, M. 2010. Production and quality assessment of fish pickles from mola (Amblypharyngodon mola) fish. Bangladesh Journal of Fisheries Research, 14 (1-2): 87-96.

Pourshamsian K, Ghomi MR, Nikoo M. 2012. Fatty Acid and Proximate Composition of Farmed Great Sturgeon (Huso huso) Affected by Thawing Methods, Frying Oils and Chill Storage. Advanced Studies in Biology, 4(2):67-76.

Product Technology, 9(3): 71-75.

properties of eleven underutilized tropical marine fish species. Journal of Aquatic Food

Sarker ZI, Elgadir MA, Ferdosh S, et al. 2012. Effect of some biopolymers on the rheological behavior of surimi gel. Molecules, 17(5):5733-5744. https://doi.org/10.3390/molecules 17055733 PMid:22628045

Sharma, P.J. and Sarma, J. 2012. Preparation of Pickles from Fresh Water Fish and Their Changes during Storage. Environment and Ecology, 30(3): 478-480.

Smida MAB, Bolje A, Ouerhani A, et al. 2014. Effects of Drying on the Biochemical Composition of Atherina boyeri from the Tunisian Coast. Food and Nutrition Sciences. 5(14):1399-1407. https://doi.org/10.4236/fns.2014. 514152

Sriket P, Benjakul S, Visessanguan W, et al. 2007. Comparative studies on the effect of the freeze-thawing process on the physicochemical properties and microstructures of 
black tiger shrimp (Penaeus monodon) and white shrimp (Penaeus vannamei) muscle. Food Chemistry, 104(1):113-121.

https://doi.org/10.1016/j.foodchem. 2006.11.004

Stansby, M.B. 1962. Proximate composition of fish. Fish in Nutrition. In: E Heen, R Ercnzer (Editors) Fishing News
(Books). Ltd. Ludgate, 110 Fleet Street London, E.G. 4, England.

Tanuja, D. and Hameed, M.S. 1998. Preparation and storage studies of squilla pickle. School of Industrial Fisheries, Cochin University of Science and Technology Fine Arts Avenue, Cochin, India. 3: 24-28. 